\title{
SATISFACTION OF COMPANIONS WITH THE EXPERIENCE OF SUPPORTING THE PARTURIENT AT A UNIVERSITY HOSPITAL
}

\author{
Odaléa Maria Brüggemann¹, Joyce Green Koettker², Manuela Beatriz Velho³, Juliana Jacques da Costa \\ Monguilhott ${ }^{4}$, Marisa Monticelli ${ }^{5}$
}

\begin{abstract}
${ }^{1} \mathrm{PhD}$ in Tocogynecology. Professor, Graduate Department and Programa de Pós-Gradução em Enfermagem (PEN), Universidade Federal de Santa Catarina (UFSC). CNPq Researcher. Florianópolis, Santa Catarina, Brazil. E-mail: odalea.bruggemann@ufsc.br

${ }^{2}$ Doctoral student, PEN/UFSC. Reuni Grant. Florianópolis, Santa Catarina, Brazil. E-mail: joycegreenk@yahoo.com.br

${ }^{3}$ Doctoral student, PEN/UFSC. Florianópolis, Santa Catarina, Brazil. E-mail: manuelavelho@hotmail.com

${ }^{4}$ Doctoral student, PEN/UFSC. Florianópolis, Santa Catarina, Brazil. E-mail: jujdacosta@gmail.com

${ }^{5} \mathrm{PhD}$ in Nursing. Retired professor, Department of Nursing, PEN/UFSC. Florianópolis, Santa Catarina, Brazil. E-mail: marisamonticelli123@gmail.com
\end{abstract}

\begin{abstract}
A cross-sectional study that aimed to assess the satisfaction of companions with the experience of supporting the parturient, and to identify the related factors. Data were collected at a university hospital in Southern Brazil, by means of semistructured interviews with 314 caregivers, between October of 2009 and January of 2010. The satisfaction scores were determined by the Cronbach's alpha coefficient. The Kruskal-Wallis and the Mann-Whitney tests estimated the related factors. The mean satisfaction of the companions was high in three domains: 1) How the woman and the newborn were cared for $(92,6$; SD=11.5), 2) Welcoming in each place $(89,9 ; \mathrm{SD}=12.9)$, and 3) Explanation about what was happening $(88,9 ; \mathrm{SD}=14.1)$. The educational level was statistically related to the satisfaction in domain 3, not being present in the delivery room was statistically related to domain 1 , and not receiving instructions from the physician regarding his role was statistically related to domain 2 . The companions manifested high satisfaction with the experience of providing support to the women.
\end{abstract}

DESCRIPTORS: Maternal health services. Health services evaluation. Consumer satisfaction. Patient satisfaction. Parturition.

\section{SATISFAÇÃO DOS ACOMPANHANTES COM A EXPERIÊNCIA DE APOIAR A PARTURIENTE EM UM HOSPITAL UNIVERSITÁRIO}

RESUMO: Estudo transversal que objetivou avaliar a satisfação dos acompanhantes com a experiência de apoiar a parturiente e identificar fatores associados. Os dados foram coletados em um hospital universitário do Sul do Brasil, através de entrevistas semiestrututradas com 314 acompanhantes, entre outubro de 2009 e janeiro de 2010. Foram construídos escores de satisfação com o coeficiente alpha de Cronbach. Os testes Kruskal-Wallis e Mann-Whitney estimaram fatores associados. A média de satisfação dos acompanhantes foi elevada nos três domínios: 1) Como cuidaram da mulher e do recém-nascido (92,6;dp=11.5); 2) Recepção em cada local (89,9;dp=12.9); e 3) Explicações sobre o que estava acontecendo $(88,9 ; \mathrm{dp}=14.1)$. A escolaridade esteve estatisticamente associada à satisfação no domínio 3 , bem como não estar presente na sala de parto com o domínio 1 e não receber orientação do médico sobre seu papel com o domínio 2. Os acompanhantes demonstram elevada satisfação com a experiência de prover apoio à mulher.

DESCRITORES: Serviços de saúde materna. Avaliação de serviços de saúde. Satisfação dos consumidores. Satisfação do paciente. Parto.

\section{SATISFACCIÓN DE ACOMPAÑANTES CON LA EXPERIENCIA DE APOYAR A LA PARTURIENTE EN UN HOSPITAL UNIVERSITARIO}

RESUMEN: Estudio transversal dirigido a evaluar la satisfacción de acompañantes con la experiencia de apoyar a la parturiente e identificar factores asociados. Los datos fueron obtenidos en un hospital universitario del Sur de Brasil, mediante entrevistas semi estructuradas con 341 acompañantes, entre Octubre 2009 y Enero 2010. Fueron construidos indicadores de satisfacción utilizando el coeficiente alpha de Cronbach. Los tests Kruskal-Wallis y Mann-Whitney estimaron factores asociados. El promedio de satisfacción de los acompañantes fue alto en los 3 dominios: 1$)$ Cuidados a la mujer y al recién nacido $(92,6$; ds=11.5), 2)Recepción en cada lugar $(89,9 ; d s=12.9)$ y 3) Explicaciones sobre lo que estaba sucediendo (88,9; ds=14.1). La escolaridad estuvo estadísticamente asociada a la satisfacción en dominio 3, así como no estar presente en la sala de parto con dominio 1 y no recibir instrucciones del médico con dominio 2. Los acompañantes demuestran una alta satisfacción con la experiencia de apoyar a la mujer.

DESCRIPTORES: Servicios de salud materna. Evaluación de servicios de salud. Satisfacción de los consumidores. Satisfacción del paciente. Parto. 


\section{INTRODUCTION}

Support during labor and delivery has been highlighted as a useful practice that should be stimulated. According to the World Health Organization (WHO), support can be provided by a person within the social network of the woman, and/or by someone trusted by the woman, i.e., her partner, a nurse, a friend or a female companion. ${ }^{1}$

The benefits of the partner's presence are known to reduce the length of time in labor, the use of medications and analgesia, and the number of operative deliveries and neonatal depression ${ }^{1-2}$. It is also known that women's satisfaction with the experience of labor and birth is greater when they have someone present to give them support. ${ }^{3}$ Even when companions have no previous training, their presence is able to offer the necessary emotional support, providing security by means of words and gestures of affection and comfort..$^{3-5} \mathrm{~A}$ systematic review published in the Cochrane Library, which analyzed 22 randomized controlled trials with 15,288 women, showed that women in the intervention group (with continued support) more frequently had spontaneous delivery (without the use of forceps, vacuum or need for a cesarean section), less frequently used intrapartum analgesia, were more satisfied, had a reduction in labor time; and their newborns (NBs) had a lower frequency of low five-minute Apgar, suggesting that all parturients should receive continuous support. ${ }^{2}$

In Brazil, Law n.11.108 was published in 2005 , to ensure that women have a companion of their choice during labor, delivery and the immediate postpartum periods, thereby forcing the health care services of the National Health Care System (Sistema Único de Saúde, SUS), either public or private partners, to adopt this practice. ${ }^{6}$ Since its publication, a movement to include companions has been observed in health care institutions that provide care, but it is not yet a reality in all of them. A multicenter study with 23,979 women showed that $75.5 \%$ had a companion during hospitalization for delivery, but only $18.8 \%$ had a continuous companion at all times during labor, delivery and the postpartum period, as required by the Law. In this study, $71.2 \%$ of maternal charts lacked information on the presence of a companion, which reflects the low importance given to this Law. ${ }^{7} \mathrm{~A}$ qualitative study performed in Santa Catarina showed, through the nurses' statements, that the main factors preventing the presence of a companion as chosen by the parturient were related to the decisions of professionals at the time of care, and the inadequacy of the organizational structure. ${ }^{8}$

In the Brazilian context, the companion in the woman's social network has assumed the role of support provider during labor and delivery. Some studies have investigated the users' satisfaction regarding the support received during hospitalization, ${ }^{9-10}$ which actions the companion performed to develop the role of supporter, and their experience and perceptions about this role. ${ }^{11-12}$ However, the companions' satisfaction when exercising their function has not been a frequent object of study, which makes it necessary to analyze the aspects involved in this practice and the internal repercussions that this kind of experience causes in the companions themselves, revealing the factors that can and cannot be associated to their satisfaction. This knowledge can help professionals, managers in health care services, and public policy makers reconsider the form of inclusion of the companion in the current model.

The objective of this study was to assess the satisfaction of the companions regarding the experience of supporting the parturient in the obstetrical center (OC) of a university hospital (UH) in southern Brazil, and to identify the factors associated with satisfaction.

\section{METHOD}

This was a cross-sectional study developed in the maternity ward of the UH at Santa Catarina Federal University (UFSC), which includes the obstetric screening (TS), the OC and the Roomingin setting (RIS).$^{13}$ Since 1995, the presence of a companion, as chosen by the woman, is stimulated by maternity professionals from the moment she enters the institution until hospital discharge. This practice was established and is maintained due to the cares philosophy which aims to promote user participation as subjects of health care, in partnership with professionals. ${ }^{14}$

Data were collected from October of 2009 to January of 2010. The sample was intentional, its size being calculated based on the performance of 1,500 annual births in the UH. The mothers' satisfaction with care received was estimated to be $50 \%$, with a confidence interval of $95 \%$ and a maximum error of 5\%, resulting in 310 women. This was a sample calculation from a larger study entitled, "Care philosophy of a maternity care-school: factors associated with satisfaction of women users" ${ }^{\prime \prime}$. The existence of a companion 
was estimated for each of them, with the same parameters being applied; therefore, $310 \mathrm{com}$ panions should be interviewed. The companions of women who had a normal birth or a cesarean section and remained in the OC were included. The companions of mothers who had had an elective cesarean section, companions of mothers who had a NB admitted to the Neonatal Intensive Care Unit (NICU), or whose fetus or newborn died were excluded, because these situations could influence the answers regarding satisfaction with the care provided .

A questionnaire was administered by means of an interview, which was tested in the first phase of the study with ten patients, and the questions that were not fully understood were reformulated. Three hundred fourteen companions were interviewed in the RIS within the first 24 hours after birth. There was no refusal to participate in the study. All respondents signed a consent form. The project was approved by the Ethics Committee in Research with Human Beings, Protocol n.263/07.

The three interviewers, students of the undergraduate nursing course, were previously trained by the project coordinators, in order to answer questions about the selection of subjects, the questionnaires and approach during the interview. For the selection of subjects, the interviewers went to the RIS from Monday to Friday, in the early afternoon, to identify companions who met the inclusion criteria and invite them to participate in the study.

The questionnaire consisted of 26 questions, divided into three sections with questions on sociodemographic characteristics, the experience of being a companion and satisfaction with the experience. The studied variables and their categories were: age (in years, categorized as: up to 25, 26-30, $31-40$, above 40 ); education (incomplete primary education, complete primary education, complete secondary education, and complete higher education); marital status (married, common-law marriage, single, separated, divorced and widow(ed); race (white, black, brown/indigenous); relationship with the puerperal woman (partner, mother, baby's father, and others); previous experience as a companion (no, yes/UH, yes/another maternity service); acquaintance with the maternity service at the UH before accompanying the mother (not answered, yes, no); participation in a lecture or course about pregnant women (not answered, yes, no); the professional introduced him/herself (not answered, yes, no, does not remember, some); instructions on the companion role (not answered, yes, no, does not remember); professional who instructed (nurse, nursing auxiliary/technician, physician); areas where stayed as a companion (pre-delivery, delivery room, postpartum recovery room); level of satisfaction about staff being welcoming; about the stimulus to participate in care; about the explanations on assistance and the process experienced by the woman; about instructions on their role; and care provided to the woman and the newborn.

As for the variable satisfaction, the responses were obtained from a sequence of five symbols with facial expressions, shown to the companion so that he/she pointed to the one corresponding to how he/she felt about the staff welcoming, the instructions on his/her role, how he/she took care of the woman and the NB, the explanations received on the assistance and the process experienced by the woman (very satisfied, satisfied, indifferent, dissatisfied or very dissatisfied) in the OC, accompanying the woman during pre-delivery, delivery, and also the newborn in immediate care room. The responses "satisfied" and "very satisfied" were considered indicative of satisfaction. ${ }^{15}$

The data were entered into EPI INFO - version 2002, organized and analyzed using descriptive statistics (absolute and relative frequency, mean and standard deviation). To assess satisfaction, principal and confirmatory factor analyses were performed, and the Cronbach's alpha coefficient was used for the construction of satisfaction scores. The Cronbach's alpha coefficient, considering all the questions, is estimated at 0.952 , and no question had to be reversed because the correlations were all positive. Only three questions had a correlation below 0.5 with the total value, therefore they were eliminated and the analysis continued (data not shown). Thereafter, the principal factor analysis revealed questions with a low correlation with the total variability (flag $<0.5$ - rotated factor loadings) and six questions were excluded. The confirmatory factor analysis, considering only the questions that were not eliminated, revealed the need for four factors (eigenvalue $>1$ ) with a power of $77.7 \%$ of explanation of the total variability. The researchers' assessment, however, found that two domains concerned the same subject, therefore building three domains: Domain 1) satisfaction with the received explanations; Domain 2) satisfaction with welcoming in each care area; and Domain 3) satisfaction with the care for the woman 
and the NB. The domain scores were obtained by summing the scores on each question and turning on a scale from 0 to 100 (data not shown). After defining the satisfaction scores, the association of each of the questions in the research was studied regarding the satisfaction in the domains (scores ranging from 0 to 100), by using statistical tests such as ANOVA or Kruskal-Wallis or the Mann-Whitney test, as the scores themselves did not have a normal distribution (assessed by the Kolmogorov-Smirnov test). The level of significance was assumed at 5\% and the software used for analysis was Statistical Package for the Social Sciences (SPSS).

\section{RESULTS}

The sociodemographic characteristics of some aspects of the experience of the companions are shown in Table 1. Most were the parturient's partners $(70.1 \%)$, had their first experience as a companion in a maternity service (72.3\%), had not participated in groups of pregnant women $(89.2 \%)$, had not previously known the UH $(67.26 \%)$, reported that the professionals introduced themselves $(81.2 \%)$, that they had received instructions on their role $(92.7 \%)$, and the nurse was the main professional who provided that information (57.6\%) (Table 1).

Table 1 - Sociodemographic characteristics and experience of companions. Florianópolis, SC, 2009$2010(n=314)$

\begin{tabular}{|c|c|c|}
\hline Variable & $\mathbf{n}$ & $\%$ \\
\hline Age (median) & \multicolumn{2}{|c|}{$29(15-62)$} \\
\hline \multicolumn{3}{|l|}{ Education } \\
\hline Incomplete primary education & 55 & 17.6 \\
\hline Complete primary education & 116 & 36.9 \\
\hline Complete secondary education & 120 & 38.2 \\
\hline Complete high education & 23 & 7.3 \\
\hline \multicolumn{3}{|l|}{ Race } \\
\hline White & 277 & 88.2 \\
\hline Black & 26 & 8.3 \\
\hline Brown/Indigenous & 11 & 3.5 \\
\hline \multicolumn{3}{|l|}{ Relationship } \\
\hline Partner & 220 & 70.1 \\
\hline Others & 26 & 8.3 \\
\hline Mother & 39 & 12.4 \\
\hline Baby's father & 29 & 9.2 \\
\hline \multicolumn{3}{|l|}{ Previous experience as a companion } \\
\hline No & 227 & 72.3 \\
\hline Yes/UH & 32 & 10.2 \\
\hline Yes/other maternity service & 55 & 17.5 \\
\hline \multicolumn{3}{|c|}{ Acquaintance with the maternity service } \\
\hline Yes & 103 & 32.8 \\
\hline No & 211 & 67.2 \\
\hline \multicolumn{3}{|c|}{ Lecture or course about pregnant women } \\
\hline Yes & 34 & 10.8 \\
\hline No & 280 & 89.2 \\
\hline \multicolumn{3}{|l|}{ Professionals introduced themselves } \\
\hline Yes & 255 & 81.2 \\
\hline No & 26 & 8.3 \\
\hline Some & 33 & 10.5 \\
\hline
\end{tabular}




\begin{tabular}{lrc}
\hline & & Conclusion \\
\hline Variable & $\mathbf{n}$ & \% \\
\hline Instruction on the companion role & 291 & \\
Yes & 23 & 72.7 \\
No & & 7.3 \\
Professional who instructed & 247 & 57.6 \\
Nurse & 122 & 28.4 \\
Physician & 60 & 14.0 \\
Nursing auxiliary/technician & & \\
\hline
\end{tabular}

Table 2 shows that the companions usually felt satisfied in all OC sites. However, it should be noted that satisfaction with staff swelcoming in the delivery room was less frequent $(68.9 \%)$.

Table 2 - Degree of satisfaction of the companions in pre-delivery, delivery and postpartum recovery room. Florianópolis, SC, 2009-2010 $(n=314)$

\begin{tabular}{lcccc}
\hline & \multicolumn{3}{c}{ Level of satisfaction } \\
\cline { 2 - 5 } & Satisfied & Indifferent & Dissatisfied & Not applicable \\
\hline Pre-delivery room & $\mathbf{n}(\%)$ & $\mathbf{n}(\%)$ & $\mathbf{n}(\%)$ & $\mathbf{n}(\%)$ \\
Staff welcoming & $290(92,3)$ & $13(4,1)$ & $3(0,9)$ & $8(2,5)$ \\
Stimulus to participate in care & $278(88,5)$ & $21(6,7)$ & $5(1,6)$ & $10(3,2)$ \\
$\quad$ Explanations about assistance and the process experienced & $284(90,4)$ & $17(5,4)$ & $7(2,2)$ & $6(1,9)$ \\
by the woman & $256(81,5)$ & $32(10,2)$ & $12(3,8)$ & $14(4,5)$ \\
$\quad$ Instructions about the companion role & $289(92,0)$ & $11(3,5)$ & $7(2,2)$ & $7(2,2)$ \\
$\quad$ Care for the woman & & & & \\
Delivery room & $210(68,9)$ & $96(30,6)$ & $8(2,5)$ & --- \\
Staff welcoming & $275(86,9)$ & $17(5,4)$ & $3(0,9)$ & $21(6,7)$ \\
Stimulus to participate in care & $278(88,2)$ & $15(4,8)$ & $2(0,6)$ & $20(6,4)$ \\
Explanations about assistance and the process experienced \\
by the woman & $254(80,9)$ & $23(7,3)$ & $10(3,2)$ & $27(8,6)$ \\
$\quad$ Instructions about the companion role & $285(90,8)$ & $8(2,5)$ & $1(0,3)$ & $20(6,4)$ \\
Care for the woman & & & & \\
Room for newborn care & $293(93,3)$ & $07(2,2)$ & $1(0,3)$ & $13(4,1)$ \\
$\quad$ Staff welcoming & $284(90,4)$ & $15(4,8)$ & $3(1,3)$ & $11(3,5)$ \\
Stimulus to participate in care & $290(92,4)$ & $11(3,5)$ & $2(0,6)$ & $11(3,5)$ \\
Explanations about assistance and the process experienced \\
by the woman & $263(83,8)$ & $20(6,4)$ & $12(3,8)$ & $19(6,1)$ \\
Instructions about the companion role & $294(93,6)$ & $8(2,5)$ & ---- & $12(3,8)$ \\
Care for the woman & &
\end{tabular}

The mean satisfaction in all three areas was high, $92.6(\mathrm{SD}=11.5)$ in the domain - "how they took care of the woman and the NB", 89.9 $(\mathrm{SD}=12.9)$ in the domain "staff welcoming in each care area", and $88.9(\mathrm{SD}=14.1)$ in the domain "explained what was happening." As for the sociodemographic variables, the companions who completed secondary school were more satisfied $(p=.0439)$ with the received explanations, the lowest mean level of satisfaction being the one of the companions who had higher education (Table 3).

The companions who were not present in the delivery room felt more satisfied with the care for the women and the NBs $(p=0.0105)$ (Table 4). Those who had not received instruction from the physician about their role were more satisfied with staff welcoming $(p=0.0431)$ (Table 5). Those who did not receive the information requested in the delivery room were more satisfied with care for the women and NBs $(p=0.0002)$ (Table 5). 
Table 3 - Association of the satisfaction scores in each studied domain according to the sociodemographic characteristics of the companions. Florianópolis, SC, 2009-2010 (n=292*)

\begin{tabular}{|c|c|c|c|c|c|c|c|c|c|c|c|c|c|c|c|}
\hline & \multicolumn{5}{|c|}{$\begin{array}{c}\text { Domain } 1 \\
\text { Explained what was } \\
\text { happening } \\
\end{array}$} & \multicolumn{5}{|c|}{$\begin{array}{c}\text { Domain } 2 \\
\text { Staff welcoming in each care } \\
\text { area }\end{array}$} & \multicolumn{5}{|c|}{$\begin{array}{c}\text { Domain } 3 \\
\text { Care for the woman and } \\
\text { the NB } \\
\end{array}$} \\
\hline & $\mathbf{n}$ & Mean & SD & Median & pt & $\mathbf{n}$ & Mean & SD & Median & $\mathrm{pt}$ & $\mathbf{n}$ & Mean & SD & Median & $\mathrm{pt}$ \\
\hline \multicolumn{16}{|l|}{ Age } \\
\hline Up to 25 & 84 & 88.6 & 13.7 & 98.2 & & 84 & 88.5 & 14.2 & 93.8 & & 84 & 92.1 & 12.6 & 97.5 & \\
\hline 26 to 30 & 85 & 88.1 & 15.3 & 96.4 & & 85 & 89.3 & 13.6 & 95.8 & & 85 & 91.3 & 12.6 & 95.0 & \\
\hline 31 to 40 & 77 & 88.9 & 14.0 & 96.4 & & 77 & 90.9 & 10.8 & 95.8 & & 77 & 93.5 & 9.5 & 100.0 & \\
\hline$>40$ & 46 & 90.8 & 12.5 & 100.0 & & 46 & 92.1 & 12.2 & 100.0 & & 46 & 94.5 & 10.2 & 100.0 & \\
\hline Education & & & & & 0.0439 & & & & & 0.5893 & & & & & 0.2256 \\
\hline Incomplete primary education & 52 & 86.6 & 15.1 & 96.4 & & 52 & 90.5 & 13.1 & 100.0 & & 52 & 91.9 & 11.6 & 95.0 & \\
\hline Complete primary education & 107 & 89.8 & 15.4 & 100.0 & & 107 & 90.2 & 13.7 & 100.0 & & 107 & 93.0 & 12.6 & 100.0 & \\
\hline Complete secondary education & 113 & 90.2 & 11.6 & 96.4 & & 113 & 89.8 & 12.2 & 95.8 & & 113 & 93.1 & 10.4 & 100.0 & \\
\hline Complete high education & 20 & 82.5 & 14.7 & 75.0 & & 20 & 88.1 & 12.2 & 91.7 & & 20 & 89.8 & 11.5 & 95.0 & \\
\hline Race & & & & & 0.0595 & & & & & 0.8709 & & & & & 0.2892 \\
\hline White & 259 & 89.3 & 13.9 & 96.4 & & 259 & 90.2 & 12.7 & 95.8 & & 259 & 92.9 & 11.4 & 100.0 & \\
\hline Black & 23 & 82.6 & 15.3 & 85.7 & & 23 & 87.7 & 15.4 & 100.0 & & 23 & 88.9 & 13.2 & 90.0 & \\
\hline Brown/Indigenous & 10 & 92.1 & 12.9 & 100.0 & & 10 & 88.8 & 12.1 & 91.7 & & 10 & 94.5 & 7.3 & 97.5 & \\
\hline Relationship & & & & & 0.1742 & & & & & 0.2928 & & & & & 0.3101 \\
\hline Partner & 202 & 89.0 & 13.4 & 96.4 & & 202 & 90.0 & 12.3 & 95.8 & & 202 & 92.8 & 10.7 & 100.0 & \\
\hline Mother & 35 & 90.2 & 13.1 & 100.0 & & 35 & 92.6 & 11.6 & 100.0 & & 35 & 93.3 & 10.5 & 100.0 & \\
\hline Baby's father & 29 & 83.9 & 18.7 & 92.9 & & 29 & 86.1 & 15.7 & 91.7 & & 29 & 87.8 & 17.0 & 95.0 & \\
\hline Others & 26 & 92.2 & 13.4 & 100.0 & & 26 & 90.1 & 14.8 & 97.9 & & 26 & 95.8 & 10.6 & 100.0 & \\
\hline
\end{tabular}

* The answers "not applicable" were excluded; † Mann-Whitney test or Kruskal-Wallis.

Table 4 - Association of the satisfaction scores in each studied domain according to the companions' participation in lectures or courses, their stay in pre-delivery and delivery rooms, and the introduction by the professionals. Florianópolis, SC, 2009-2010 ( $\left.n=292^{*}\right)$

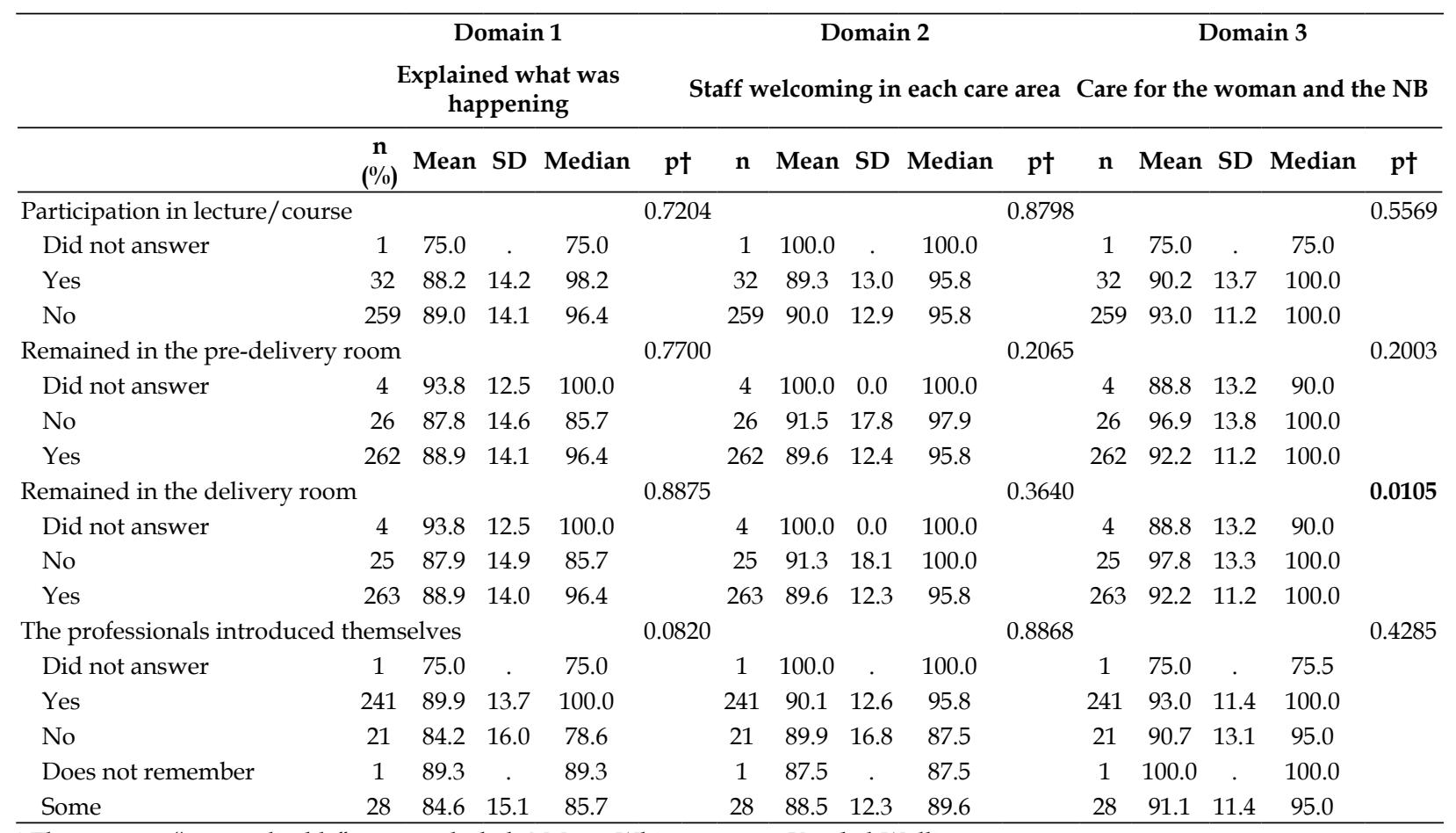

* The answers "not applicable" were excluded; † Mann-Whitney test or Kruskal-Wallis. 
Table 5 - Association of the satisfaction scores with the instructions and care, with information required from professionals. Florianópolis - SC, 2009-2010 $\left(n=292^{*}\right)$

\begin{tabular}{|c|c|c|c|c|c|c|c|c|c|c|c|c|c|c|c|}
\hline & Explai & ined wl & hat w & $\begin{array}{l}\text { in } 1 \\
\text { vas happe }\end{array}$ & ening & Staf & f welco & $\begin{array}{r}\text { Domai } \\
\text { oming } \\
\text { area }\end{array}$ & $\begin{array}{l}\text { in } 2 \\
\text { in each } c\end{array}$ & & Care & $\begin{array}{r}\text { Do } \\
\text { for the }\end{array}$ & $\begin{array}{l}\text { omair } \\
\text { e won } \\
\text { NB }\end{array}$ & nan and $\mathrm{t}$ & \\
\hline & $\begin{array}{c}\mathbf{n} \\
(\%)\end{array}$ & Mean & SD & Median & p & $\mathbf{n}$ & Mean & SD & Median & p & $\mathbf{n}$ & Mean & SD & Median & $\mathrm{p}$ \\
\hline $\begin{array}{l}\text { Instructions in the pre-delive } \\
\text { room }\end{array}$ & very & & & & 0.4222 & & & & & 0.5044 & & & & & 0.3123 \\
\hline Did not answer & 43 & 87.5 & 15.6 & 96.4 & & 43 & 90.3 & 13.5 & 95.8 & & 43 & 89.3 & 14.5 & 95.0 & \\
\hline Not in this care area & 61 & 87.4 & 15.0 & 92.9 & & 61 & 89.2 & 14.4 & 95.8 & & 61 & 91.9 & 12.2 & 95.0 & \\
\hline Yes & 188 & 89.7 & 13.4 & 100.0 & & 188 & 90.1 & 12.3 & 100.0 & & 188 & 93.6 & 10.3 & 100.0 & \\
\hline $\begin{array}{l}\text { Instructions in the delivery } \\
\text { room }\end{array}$ & & & & & 0.8257 & & & & & 0.4786 & & & & & 0.3123 \\
\hline Did not answer & 43 & 87.5 & 15.6 & 96.4 & & 43 & 90.3 & 13.5 & 95.8 & & 43 & 89.3 & 14.5 & 95.0 & \\
\hline Not in this care area & 65 & 88.0 & 15.4 & 92.9 & & 65 & 90.6 & 14.6 & 95.8 & & 65 & 93.2 & 12.9 & 95.0 & \\
\hline Yes & 184 & 89.5 & 13.2 & 100.0 & & 184 & 89.6 & 12.1 & 95.8 & & 184 & 93.2 & 10.0 & 100.0 & \\
\hline Instructions from the nurse & & & & & 0.2720 & & & & & 0.5107 & & & & & 0.2672 \\
\hline Did not answer & 24 & 84.1 & 18.3 & 87.5 & & 24 & 89.9 & 14.4 & 97.9 & & 24 & 93.1 & 13.5 & 100.0 & \\
\hline No & 43 & 85.9 & 17.0 & 85.7 & & 43 & 89.3 & 13.5 & 95.8 & & 43 & 91.1 & 11.3 & 95.0 & \\
\hline Yes & 225 & 90.0 & 12.8 & 100.0 & & 225 & 90.0 & 12.6 & 95.8 & & 225 & 92.8 & 11.3 & 100.0 & \\
\hline $\begin{array}{l}\text { Instruction from the nursing } \\
\text { auxiliary/technician }\end{array}$ & & & & & 0.7326 & & & & & 0.6580 & & & & & 0.5235 \\
\hline Did not answer & 24 & 84.1 & 18.3 & 87.5 & & 24 & 89.9 & 14.4 & 97.9 & & 24 & 93.1 & 13.5 & 100.0 & \\
\hline No & 215 & 89.2 & 13.7 & 96.4 & & 215 & 89.9 & 12.8 & 95.8 & & 215 & 92.4 & 11.6 & 100.0 & \\
\hline Yes & 53 & 89.9 & 13.3 & 100.0 & & 53 & 90.2 & 12.8 & 100.0 & & 53 & 93.4 & 10.2 & 100.0 & \\
\hline $\begin{array}{l}\text { Instruction from the } \\
\text { physician }\end{array}$ & & & & & 0.3566 & & & & & 0.0431 & & & & & 0.3309 \\
\hline Did not answer & 24 & 84.1 & 18.3 & 87.5 & & 24 & 89.9 & 14.4 & 97.9 & & 24 & 93.1 & 13.5 & 100.0 & \\
\hline No & 160 & 89.8 & 14.3 & 100.0 & & 160 & 90.9 & 13.2 & 100.0 & & 160 & 92.9 & 11.4 & 100.0 & \\
\hline Yes & 108 & 88.5 & 12.5 & 91.1 & & 108 & 88.5 & 12.1 & 91.7 & & 108 & 92.0 & 11.3 & 95.0 & \\
\hline $\begin{array}{l}\text { Received information reques } \\
\text { in the delivery room }\end{array}$ & ested & & & & 0.4778 & & & & & & & & & & 0.0002 \\
\hline Did not answer & 24 & 83.0 & 17.5 & 85.7 & & 24 & 87.0 & 19.3 & 91.7 & 0.4061 & 24 & 85.6 & 17.3 & 90.0 & \\
\hline Not in this care area & 15 & 90.7 & 13.6 & 96.4 & & 15 & 92.2 & 11.8 & 95.8 & & 15 & 102.3 & 8.4 & 100.0 & \\
\hline Yes & 253 & 89.3 & 13.7 & 100.0 & & 253 & 90.1 & 12.2 & 95.8 & & 253 & 92.7 & 10.5 & 100.0 & \\
\hline $\begin{array}{l}\text { Stimulus to participate in ca } \\
\text { for the woman }\end{array}$ & & & & & 0.8525 & & & & & 0.2435 & & & & & 0.1477 \\
\hline Yes & 283 & 89.0 & 13.8 & 96.4 & & 283 & 90.1 & 12.7 & 95.8 & & 283 & 92.8 & 11.2 & 100.0 & \\
\hline No & 9 & 84.5 & 20.7 & 96.4 & & 9 & 85.2 & 17.1 & 83.3 & & 9 & 85.6 & 18.5 & 85.0 & \\
\hline
\end{tabular}

* The answers "not applicable" were excluded; † Mann-Whitney test or Kruskal-Wallis.

\section{DISCUSSION}

The studied sample differs from some studies in which the chosen companions were female (mother, sister or friend), ${ }^{11,16}$ but it is similar to most studies in which the partner also played that role, ${ }^{7,9,17-18}$ which shows that women have been choosing who will stay with them. The presence of partners in the delivery scenario can be considered recent, because it occurred in the 1990s. However, in some situations, this presence went from an occasional event to a true prerogative for support. One should remember that the partner is also emotionally involved and sharing the experience, and may himself need support. ${ }^{19}$ The relationship of most companions in the present study also meets the national data provided by the study "Being Born in Brazil," in which the most frequent companion was the woman's partner in all labor phases (35.4\%). ${ }^{7}$ Although many women worry about their partners' reaction at delivery because they witness the changes in the body, ${ }^{20}$ most of them choose to include the partner in the delivery process, as it contributes to an early connection between the father and the baby, and often strengthens the couple's connection.

Among the characteristics related to the companions' experiences, the high frequency of lack of participation in educational activities during pre-delivery care is emphasized, which 
may be related to the fact that women themselves often do not participate, ${ }^{16}$ even in this institution. ${ }^{9}$ However, it is a practice that should be encouraged because there are positive aspects arising from the participation of pregnant women and their companions in educational groups. ${ }^{12,21}$ In addition to not attending courses, for most of the respondents this was their first experience as a companion on a maternity service and they had not previously known the institution. These findings support the assumption that, despite the importance, integrating the companion in pre-delivery care, participating in some type of training or prior awareness course are prerequisites for the companion to fulfill his/her role, since these aspects were not associated with companion's satisfaction in any of the analyzed satisfaction domains.

In this context, the presence of a companion as chosen by the women is a humanizing aspect of care, to the extent that his/her presence and support to the parturient contributes to the health care professionals' rethinking of the meaning of birth, and starting to have a more humane and less routine attitude. ${ }^{11}$

Results of a national hospital-based survey demonstrated that women who had companions reported more satisfaction with the care provided, received more information, felt more respected by professionals, and less frequently reported any form of violence during hospitalization. ${ }^{22}$ Moreover, when analyzing the data from this survey regarding southern Brazil, the presence of the companion during labor and delivery contributed to the reduction of interventions such as shaving, enemas, the Kristeller maneuver and the adoption of good practices, such as non-pharmacological methods of pain relief and early skin-to-skin contact. $^{23}$

The prevalence of companions who reported satisfaction with the experience of accompanying the woman during labor, delivery and care provided to NBs was high. The mean satisfaction was also high in all analyzed domains. However, in the descriptive analysis, the percentage of companions satisfied with staff welcoming in the delivery room was much smaller than in other care areas. The delivery room is known as a restricted area where there is a hegemony of the health care professionals that restricts the active participation of companions. ${ }^{7}$

The health care professionals also need to rethink the type of care provided to the parturient in the delivery room, because the companions who were not present, i.e., did not witness care, felt more satisfied regarding care of the woman and the NB. When the second stage of labor is conducted forcefully by professionals and decisions are not shared, thereby extinguishing the female protagonism, birth can be surrounded by stress and traumatic factors for the parturient and her partner. In addition to the institutional violence, the parturient can suffer from misconduct of obstetric complications, such as in the shoulder dystocia of the NB and pain while performing the perineal suture. ${ }^{17}$

Although the studied maternity service has a philosophy of humane principles, in the second stage of labor the woman is still moved to another room (from pre-delivery to the delivery room) which can also be one of the reasons that contributed to the lower satisfaction of companions at this point, since there is a discontinuity of care and a change of the health care team. The World Health Organization considers the routine transfer of the parturient to another room at the beginning of the second stage of labor a practice that is often performed inadequately, ${ }^{1}$ and which can also complicate the support offered by companions and their stay in the care area in this context,. In addition, because it is a teaching hospital, usually the delivery room is full of "unknown people" who have not established previous contact with the woman and her companion, making the atmosphere less welcoming.

The fact that the companions who did not receive the requested information in the delivery were more satisfied with care for women and NBs is worrying, which makes it essential to assess the type, quality of responses and the professional approach to their questioning. A breakdown in communication in the delivery moment can make a negative impression about birth, as people become more vulnerable and in need of information. ${ }^{24}$ The right to information is a basic premise of the relationship of the health care professional with the user, fundamental to cause changes in obstetric care..$^{25}$

The type of approach of the health care professional can also influence the companions' experience because, as shown by the results of this investigation, the companions who did not receive instructions from the physician about their role were more satisfied with care received in the OC. This finding is contrary to other studies in which instruction during labor was one of the aspects associated with greater satisfaction of the partu- 
rients. ${ }^{3,9}$ Thus, it is necessary to assess the quality of instructions, because they can be imbued with rules that curtail the companions' participation and make them feel unwelcome.

It should be noted that the presence of companions in different moments of hospitalization is very different from the Brazilian reality. Preliminary results of the satisfaction study with puerperal women attended at SUS showed that the majority $(54.5 \%)$ of 83,875 women surveyed had no companion of their choice during labor, $55.2 \%$ reported that the health care service prohibited it, and $16.5 \%$ did not know that they could have had a companion. ${ }^{26}$ National data of a sample of 23,879 women show that the companion is present in different realities, but not continuously at all times of the labor process. ${ }^{7}$ In this study, $24.5 \%$ of women had no companion at any time, $56.7 \%$ had a companion at some point, and only $18.8 \%$ had a companion continuously. ${ }^{7}$ The integraton of a continuous companion is associated with institutional rules and culture, to a standard that allows a companion for women in all stages of care, and the change in ambience and furniture, thereby allowing the maximum possible comfort to the permanence of the companion. ${ }^{7}$

Despite the existence of Law n. 11108/05, the integration of companions is an institutional decision, as shown by the present study, since there is no sanction against managers or health care professionals who refuse to allow companionship, leaving them to make the decision on when and where companions can stay with the woman.

A few studied factors were associated with companions' satisfaction. However, the fact that the companions who had completed secondary education were more satisfied $(p=0.0439)$ with the received explanations than those who had a higher level of education leaves doubt about the quality of the provided instructions, since they are often people with less access to information and who are less critical. In general, users with higher educational levels are those who more often question professional attitudes, hospital routines, and are more educated about their rights and the laws of the country.

Most of the variables were not significantly associated with the satisfaction domains. This result differs from other studies in which, for example, the fact that the professionals introduced themselves to the companions or the instructions they receive influenced satisfaction. ${ }^{3,9}$

The studied companions reported that most professionals introduced themselves and provided instructions on their role in the pre-delivery and delivery rooms, especially nurses, corroborating another study that pointed to the nursing staff as responsible for most of the instructions provided to companions. ${ }^{17}$ However, these aspects were not associated with any of the analyzed satisfaction domains. This may have been due to the high prevalence of companions satisfied with the staff welcoming and care provided to the women, demonstrating that the principle of care philosophy in the maternity service, which states that the whole team should act respectfully towards the woman, the NB and the family, has been incorporated by the professionals. ${ }^{14}$

The main limitation of this study is the potential courtesy bias, since respondents may have considered the experience very positive due to the simple fact that they were allowed to participate in the birth moment, and also due to the possible fear that expressing negative aspects could result in care losses for the women they were accompanying.

The generalization of the findings must be made with caution, because the studied maternity area differs from other realities by relying on the philosophy of humanized care, and has allowed the presence of a partner since its opening in $1995 .{ }^{14}$

\section{CONCLUSIONS}

The prevalence of satisfaction by the companions is high, but the fact that the percentage of companions satisfied with staff welcoming in the delivery room was much lower than in other care areas of the maternity service demands attention. A few variables are associated with companions' satisfaction, especially a lower satisfaction of companions with a higher level of education.

Identifying factors associated with the companions' satisfaction is essential to organize the services with care targeted at the companions' needs, since their participation is essential to improve care for women in the birthing process.

The results of this study, although coming from an institution with a care philosophy that promotes the inclusion of the companion since its implementation, helps to fill the knowledge gap about the companions' experience and points out new questions that must be better studied.

Because of the scarcity of publications on the subject, most of the results were compared with research on women's satisfaction, which reveals 
the need to expand that knowledge. Thus, the performance of other quantitative studies with the same approach is suggested, aiming to support or refute the findings and to identify factors associated with companion satisfaction as a support provider. A qualitative investigation in the same institution is recommended to unveil the reasons why the companions who were not present in the delivery room felt more satisfied with the care provided to the women and the NBs; the companions who did not receive instructions from the physician about their role were more satisfied with staff swelcoming and; companions who did not receive the requested information in the delivery room, since they were more satisfied with care provided to the women and the NBs.

\section{REFERENCES}

1. Organização Mundial da Saúde. Assistência ao parto normal: um guia prático. Genebra: OMS; 1996.

2. Hodnett ED, Gates S, Hofmeyr GJ, Sakala C. Continuous support for women during childbirth. Cochrane Database of Syst Rev 2013; (4):CD003766.

3. Bruggemann OM, Parpinelli MA, Osis MJD, Cecatti JG, Neto ASC. Support to woman by a companion of her choice during childbirth: a randomized controlled trial. Reprod Health 2007 Mai-Jul; 4(5):1-7.

4. Perdomini FRI, Bonilha ALL. A participação do pai como acompanhante da mulher no parto. Texto Contexto Enferm. 2011 Jul- Set; 20(3):445-52.

5. Motta CCL, Crepaldi MA. O pai no parto e apoio emocional: a perspectiva da parturiente. Paidéia 2005 Jan-Abr; 15(30):105-18.

6. Brasil. Lei $n^{\circ} 11.108$, de 07 de abril de 2005. Altera a Lei n. 8080, de 19 de setembro de 1990, para garantir às parturientes o direito à presença de acompanhante durante o trabalho de parto, parto e pós-parto imediato, no âmbito do Sistema Único de Saúde - SUS. Diário Oficial da União, 08 abr 2005.

7. Diniz CSG, D'orsi ED, Domingues RMSM, Torres JA, Dias MAB, Schneck CA, et al. Implementação da presença de acompanhantes durante a internação para o parto: dados da pesquisa nacional Nascer no Brasil. Cad Saúde Pública. 2014; 30 (Sup):140-53.

8. Brüggemann OM, Ebsen ES, Oliveira ME, Gorayeb MK, Ebele RR. Motivos que levam os serviços de saúde a não permitirem acompanhante de parto: discursos de enfermeiros. Texto Contexto Enferm. 2014 Abr-Jun; 23(2):270-7.

9. Brüggemann OM, Monticelli M, Furtado C, Fernandes CM, Lemos FN, Gayeski ME. Filosofia assistencial de uma maternidade-escola: fatores associados à satisfação das mulheres usuárias. Texto Contexto Enferm. 2011 Out-Dez; 20(4):658-68.
10. Domingues RMSM, Santos EM, Leal MC. Aspectos da satisfação das mulheres com a assistência ao parto: contribuição para o debate. Cad Saúde Pública. 2004. 20(Sup. 1):52-62.

11. Brüggemann OM, Osis MJD, Parpinell MA. Apoio no nascimento: percepções de profissionais e acompanhantes escolhidos pela mulher. Rev Saúde Pública. 2007 Fev; 41 (1):44-52.

12. Alexandre AMC, Martins M. A vivência do pai em relação ao trabalho de parto e parto. Cogitare Enferm. 2009 Abr- Jun; 14(2):324-31.

13. Brüggemann OM, Knobel R, Siebert ERC, Boing AF, Andrezo HAF. Parto vertical em hospital universitário: série histórica, 1996 a 2005. Rev Bras Saúde Matern Infant. 2009 Abr-Jun; 9(2):189-96.

14. Santos OMB, Siebert ERC. The humanization of birth experience at the University of Santa Catarina maternity hospital. Int. J Gynaecol Obstet. 2001 Nov: 48(Sup:1):23-52.

15. Brown S, Lumley J. Satisfaction with care in labor and birth: as survey of 790 Australian women. Birth. 1994 Mar; 21(1):4-13.

16. Nakano MAS, Silva LA, Beleza CS, Stefanello J, Gomes, FA. O suporte durante o processo de parturição: a visão do acompanhante. Acta Paul Enferm. 2007 Abr-Jun; 20(2):131-7.

17. Franceschini DTB, Bonilha ANL. O acompanhante de parto no centro obstétrico de um hospital universitário [dissertação]. Porto Alegre (RS): Universidade Federal do Rio Grande do Sul, Programa de Pós-graduação em Enfermagem; 2009.

18. Koettker JG, Brüggemann OM, Dufloth RM, Knobel R, Monticelli M. Resultado de partos domiciliares atendidos por enfermeiras, de 2005 a 2009, em Florianópolis, SC. Rev Saúde Pública. 2012 Jul-Ago; 46(4):747-50.

19. Enkin MW, Keirse MJNC, Neilson J, Crowther C, Duley L, Hodnett E, Hofmeyer J. Guia para atenção efetiva na gravidez e no parto. $3^{\mathrm{a}}$ ed. Rio de Janeiro: Guanabara Koogan; 2005.

20. Tarnowsk KS, Próspero ENS, Elsen I. A participação paterna no processo de humanização do nascimento: uma questão a ser repensada. Texto Contexto Enferm. 2005; 14(Esp):103-10.

21. Lally JE, Murtagh MJ, Macphail S, Thomson R. More in hope than expectation: a systematic review of women's expectations and experience of pain relief in labour. BMC Medicine. 2008 Mar; 6(7):1-10.

22. D’orsi E, Brüggemann OM, Diniz CSG, Aguiar JM, Gusman CR, Torres JÁ, et al. Desigualdades sociais e satisfação das mulheres com o atendimento ao parto no Brasil: estudo nacional de base hospitalar. Cad Saúde Pública. 2014 Ago; 30 (Sup):154-68.

23. Monguilhott JJC. A presença do acompanhante e a implementação das boas práticas na atenção ao parto: a realidade do sul do Brasil [dissertação]. 
Florianópolis (SC): Universidade Federal de Santa Catarina, Programa de Pós-Graduação em Enfermagem; 2013.

24. Nascimento AMC, Martins M. A vivência do pai em relação ao trabalho de parto e parto. Cogitare Enferm, 2009 Abr-Jun; 14(2):324-31.

25. Serruya SJ. A arte de não fazer o errado e fazer o certo! Cad. Saúde pública. 2014 Ago; 30 (Sup):36-7.

26. Brasil. Relatório Preliminar de Pesquisa: resultados preliminares da pesquisa de satisfação com mulheres puérperas atendidas no Sistema Único de Saúde - SUS. Maio de 2012 a fevereiro de. Ministério da Saúde. Secretaria de Gestão estratégica e Participativa. Departamento de Ouvidoria Geral do SUS. 2013. 